
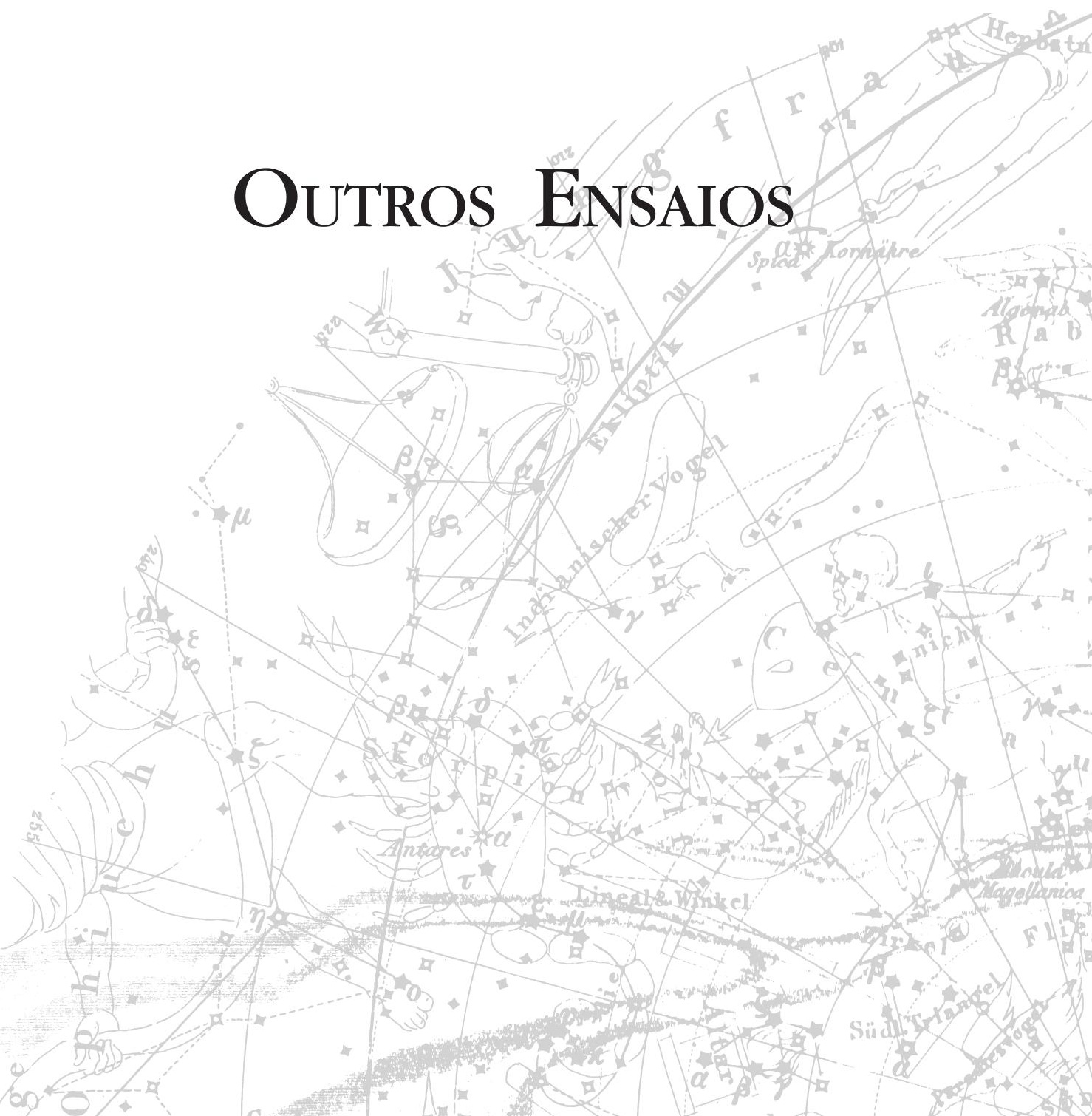



\title{
Ruínas do moderno nas ficções do pós-moderno: a ficção da crise e o pensamento trágico
}

\author{
LuCia HeLENA \\ Universidade Federal Fluminense / Pesquisadora do CNPq
}

RESUMO: PARA FOCALIZAR AS CONEXÕES ENTRE OS MODOS DE PENSAR O QUE CONSFDERAMOS AS ESTRATÉGIAS DA MODERNIDADE EM RELAÇÃO À DISCUSSÃO DA CRISE ARTÍSTICA E SOCIAL DO MUNDO CONTEMPORÂNEO DEVIDO À GLOBALIZAÇÃO, ESTE ARTIGO ANALISA TRÊS NARRATIVAS DE JOHN MAXWELL COETZEE - VIDA E ÉPOCA DE MICHAEL K (1983), DESONRA (1999) E ELIZABETH COSTELLO (2003), EM COMPARAÇÃO COM PRECURSORES EUROPEUS E BRASILEIROS, REVELANDO COMO TAIS FICÇÕES CONSTITUEM UMA FORMA DE ROMANCE DA CRISE, QUE REINVESTE NO PENSAMENTO TRÁGFCO PARA PROCEDER AO QUESTIONAMENTO DOS IMPASSES E APORIAS DA MODERNIDADE.

ABSTRACT: TO FOCUS ON THE INTERCONNECTIONS BETWEEN THE WAYS OF THINKING ABOUT WHAT WE CONSIDER TO BE THE STRATEGIES OF MODERNITY IN RELATION TO THE DISCUSSION OF THE ARTISTIC AND SOCIAL CRISIS OF THE CONTEMPORARY WORLD DUE TO GLOBALIZATION, THIS ARTICLE ANALYSES THREE NARRATIVES OF JOHN MAXWELL COETZEE - LIFE AND TIMES OF M/CHAEL K (1983), DISGRACE (1999), ELIZABETH COSTELLO (2003), COMPARING THEM WITH SOME OF THE FORERUNNERS OF THIS ATTITUDE, IN EUROPE AND IN BRAZIL, AND REVEALING HOW THEY CONSTITUTE AN EXAMPLE OF THE NOVEL OF THE CRISIS, WHICH REINVESTS IN THE TRAGIC THINKING TO CARRY OUT A QUESTIONING OF THE IMPASSES AND APORIAS OF MODERNITY.

PALAVRAS-CHAVE: FICÇÃO E GLOBALIZAÇÃO - PENSAMENTO TRÁGICO - COETZEE KAFKA - GRACILIANO RAMOS - CLARICE LISPECTOR

KEY-WORDS: FICTION AND GLOBALIZATION - TRAGIC THINKING - COETZEE - KAFKA - GRACILIANO RAMOS - CLARICE LISPECTOR 


\section{e Josef K a Michael K: câmaras de tortura}

Mas na garganta de K. colocavam-se as mãos de um dos senhores, enquanto o outro cravava a faca profundamente no seu coração e a virava duas vezes. Com os olhos que se apagavam, K. ainda viu os senhores perto de seu rosto, apoiados um no outro, as faces coladas, observando o momento de decisão. - Como um cão - disse K.

Era como se a vergonha devesse sobreviver a ele.

Franz Kafka, O processo

Certa manhã, Josef $K$. recebe em seu quarto a visita invasora de um homem estranho. Aos poucos, o mundo vai desabando sobre seus ombros, em face de uma ameaça cuja origem e cujo sentido ele não consegue identificar. A narrativa tece, com as marcas do grotesco e as cores de um expressionismo lúgubre, o teor de violência e intolerância que ultrapassaria os limites de seu próprio tempo, acrescentando reflexão pregnante ao encontro nefasto da modernidade com as forças da destruição. Já deve ter ficado claro para o leitor que estamos em Praga, no início do século XX, quando Kafka compõe a história de um homem condenado sem saber por quê, em um relato que parece antecipar o sentido trágico da História, que, em construção na Europa, cruzará o mundo e desembocará no Holocausto.

Franz Kafka (1883-1924) começou a escrever O processo na segunda semana de agosto de 1914. Seis meses mais tarde interrompe sua escrita, chegando a dizer à ex-noiva, Felice Bauer, em carta de 20 de março de 1915, que se considerava "quase incapaz" de dar continuidade ao romance. Foi acidentada e difícil a escrita de $O$ processo, que teve edição póstuma feita por Max Brod, em 1925. Na opinião de Modesto Carone, seu tradutor brasileiro, O processo pode ser concebido como uma profecia do terror nazista, em que as detenções imotivadas, os comandos de espancamento e o assassínio brutal faziam parte do cotidiano (KAFKA, 2003: 250). Sem que adote o engajamento, nem o panfleto, nem a literatura denúncia, a obra alegórica de Kafka tem a força dos textos máximos, e, de forma despojada, lança no ar o clima de suspeita, de mapeamento da alienação encoberta no dia-a-dia, desvendando a gênese de uma espécie de esquizofrenia social. 
Em 1987, na Inglaterra, John Maxwell Coetzee ${ }^{1}$ recebe pela primeira vez o Booker Prize, por seu Vida e época de Michael K. É bastante forte nessa obra, ainda que sutil e mesmo setenta anos após o início da escrita de $O$ processo, a presença de uma atmosfera de opressão e catástrofe iminente, conhecida dos leitores de Kafka. Esse é um liame que conecta os dois principais personagens da obra de Coetzee, Anna e Michael (a mãe e seu filho), a duas outras figurações criadas em outro espaço nacional: Fabiano (de Vidas secas, 1934) e Macabéa (de $A$ hora da estrela, 1977). Um elo comum, o tratamento da violência a que está submetido o homem em situações de choque, parecenos reunir Kafka, Coetzee, Ramos e Lispector a partir de textos nos quais a centelha do talento narrativo faz convergir olhar e sentimento à luz mortiça da condição humana levada aos escombros de si mesma.

Michael K é provavelmente um negro, embora em nenhuma página do romance sua etnia seja explicitada. O personagem traz à baila questões como a exclusão e a migração, sendo que a primeira está presente em todos os textos mencionados. Ele também convive com terrível opressão, sentimento familiar a Josef K. Como o Senhor K, mas sem tribunal visível, Michael está sem defesa e sem escapatória, condenado à violência e à morte por instâncias invisíveis que manifestam a crueldade e a eficiência da burocracia de Estado. Como Fabiano, Michael K encontra-se subordinado a um aparato lesivo que lhe escapa à compreensão. Esse infinito e forçado deslocamento dos personagens em direção ao concretamente inapelável remete, do mesmo modo, à figuração de Macabéa, a nordestina "de maus antecedentes", "cão sem plumas" que Lispector toma emprestado da poesia cabralina e do Nordeste desertificado de Graciliano Ramos. Um cão do qual se tirou até o que não tem: as plumas. Michael K, em sua trajetória de escape, também reenvia o leitor a Fabiano e a sua família, instados à fuga sempre inglória, sem direito a pouso nem repouso. Todos eles recortados por uma escrita que observa o real e avalia criticamente o resíduo das perdas de uma difícil jornada pela aventura da modernidade.

\footnotetext{
${ }^{1}$ Coetzee é um autor de ascendência holandesa, nascido e criado na África do Sul, com estudos na Inglaterra e nos Estados Unidos. Bastante produtivo e instigante, é autor de mais de uma dezena de romances magníficos, com os quais conquistou dois Booker Prize, em 1987 e em 2000, e também o Prêmio Nobel de Literatura, em 2003.
} 
Fabiano e sua vida seca surgem na década de 1930, no bojo do chamado romance social nordestino, pelas mãos enxutas de Graciliano Ramos. No horizonte neonaturalista das expectativas ficcionais da época, realiza-se como experiência singular de construção subjetiva e psicológica que dá livre curso à representação da vida interior, ainda que por meio da terceira pessoa narrativa. Graciliano Ramos produz uma obra marcada pela distância social que separa aquele mundo agreste da revolução social e das tentativas de modernização. Como já disse em outro lugar (HELENA, 2001: 63-76), analisando o universo da seca, Ramos demarca uma forma narrativa de subjetivação da dor e do desamparo, que já atravessou quase um século e, sem concessão ao sentimentalismo, transformou alguns de seus personagens em ícones de uma cultura de impunidade. Participante do modernismo e tratando da modernização, Graciliano Ramos reflete sobre a desilusão do progresso levado ao Nordeste a toque de caixa. Recusando a utopia da modernização a ser conseguida pela implantação da técnica a qualquer custo, seu sentido de utopia se transfere para o conceito de história e para um realismo cético que encara as forças de desagregação que desmentem qualquer modernismo heróico.

Todavia, há uma semente utópica em Vidas secas, e ela se origina do próprio conceito de História, não linear e benjaminiano, em que se apóia Graciliano Ramos (ainda que nosso escritor não tivesse lido o pensador europeu, uma vez que não se trata aqui de influência, mas de similitude de paradigmas de reflexão e de visão de mundo), e no qual o homem, manipulado pelo poder, avulta em sua penúria, roubado que foi de seu sentido pleno de existência, pela alienação social. Ramos lida, portanto, com uma utopia do precário, distinta daquela que é utilizada, por exemplo, nos Manifestos da vanguarda paulista, por um Oswald de Andrade que fez da alegria a prova dos noves de uma transformação cultural que deglutiria, em digestão bem feita, as lianas da sabedoria do colonizador. Seu sentido de utopia difere, pois, daquele que caracterizou o radicalismo inicial de nosso modernismo heróico. A utopia com que trabalha Graciliano Ramos tem em si cravada a consciência da impotência, não da impossibilidade. É uma utopia difícil de reconhecer como aquilo que vulgarmente tratamos como tal, pois não atende aos requisitos de idealização e de projeção para o futuro, que se costumam creditar ao horizonte do pensamento utópico. Esse novo sentido de utopia - a consciência da finitude e precariedade dos projetos humanos e, ao mesmo tempo, de que sem eles, mesmo precá- 
rios, a vida perde sua legitimidade e viabilidade - é o que percorre também os demais livros mencionados, nos quais um mundo de vida frágil é reservado como única possibilidade para personagens cujo estar no mundo não consegue ser tocado pela redenção, nem logra atingi-la.

Década de 1970, Rio de Janeiro: Clarice Lispector, à beira da morte, escreve $A$ hora da estrela, e nele reescreve a marcha migrante acentuada pela dolorosa escavação das vidas secas tratadas por Graciliano Ramos e, em virtude da exclusão, em outra medida, também por Kafka. Macabéa participa da estirpe dos Fabianos, dos Michael K., que não dispõem do mínimo que os habilite à decifração dos códigos e discursos disponibilizados pelas estruturas de um poder sob o qual não estão abrigados, mas que são obrigados a respeitar, atender e manter. Lispector intensifica nesse romance a discussão da autoria e da subjetividade do eu textual, presente, em modo e intensidade distintos, nos demais romances. Numa dramaturgia da subjetividade, e já fora da convivência com as utopias da plenitude, anunciadas (e "vendidas") pela modernização, Macabéa vem à luz no apagar dos sonhos do modernismo. E habita um mundo em diálogo com a mídia, que invade cada rincão, além das metrópoles povoadas de desterrados em sua própria terra.

Michael $\mathrm{K}$, ao contrário dos demais, convive com o ceticismo finissecular da passagem do século XX ao XXI. Mas tem em comum com os outros personagens dos quais o aproximamos uma acentuada operação com as ruínas do pensamento, defrontando-se com a doída escavação do mundo que a narrativa observa. Tão pungente, no pauperismo, quanto Macabéa, a consciência de Michael também não é culta e ele parece a princípio não ter noção do que o cerca. Mas pouco a pouco, ao contrário de Macabéa, sua ação diante do mundo revela uma persistência e uma poderosa afirmação de luta por cumprir um destino que, se lhe é traçado de fora, insiste em tomar sob sua rédea, ainda que pelo silêncio e pela resistência passiva, embora persistente e corajosa. Ao longo dos capítulos dessa obra intensa, Michael depara cada vez mais com a urgência de cumprir a vida na terra estiolada, em um mundo inescapavelmente eivado de assaltos, crimes e tentativas de superar o amargor das perdas e danos, em meio às estocadas dos donos do poder.

Frutos da imaginação e da circunstância sul-africana e européia e também brasileira e sul-americana, que marca é esta a reuni-los, a assinalar, na intimidade de uma diferença que os implica, esses personagens de extração tão distante, no 
tempo e no espaço? O que faz com que se aproximem essas ficções, que apresentam uma temporalidade complexa, com episódios e eras descontínuos uns dos outros e heterogêneos entre si, mas ao mesmo tempo aproximáveis?

Não há uma evidente simetria a ser resgatada entre os romances mencionados, nem um processo de desenvolvimento plano e linear que os iguale ou estabeleça uma simples equivalência entre eles. Todavia, quando observados de perto, têm um ponto de florescência que lhes é comum. Além de desenvolverem algo próximo de uma parábola social, apresentam uma forma alternativa de compreender as origens e as aventuras da modernidade e do modernismo, revelando com riqueza a temporalidade histórica diferenciada na qual se inscrevem. Partem de uma base em que o registro naturalista dos fenômenos de uma burguesia em decadência ideológica é substituído com vantagem pela releitura crítica do mesmo "naturalismo" e da situação dos "excluídos", aos quais remetem o leitor, através de textos, podemos dizer, "insurgentes" nos quais uma grande gama de práticas estéticas se apresenta em tensão com os cânones estabelecidos e consagrados pela dicção vanguardista e pela tradição romanesca do século XIX. Clarice Lispector abandona claramente o relato orgânico e cria um personagem que na ignorância formal não se distingue de Fabiano nem de Michael K. No entanto, todas essas obras recuperam a estratégica construção de um personagem frágil que é "forte", alguém que roça o sublime, por seu contrário, e é focalizado na ótica da perda, da lacuna, do resíduo, da ruína.

Sua matriz remonta a Dostoiévski e é retrabalhada por Kafka, que examina a questão da culpa numa circunstância em que o social e o individual estão extremamente imbricados. O Senhor Josef K. é, assim, uma forma narrativa mais "antiga" do que Fabiano, Macabéa e Michael K., que, até mesmo no nome, não esconde a ascendência. Trata-se, em compasso com a migração dos homens, de uma migração das idéias. No cenário e no imaginário dessas ficções, duas das principais vertentes da modernidade e do moderno estão embutidas e discutidas.

A modernidade ${ }^{2}$ (cujo florescimento se dá no século XVIII, embora a construção de seu paradigma venha de antes) revive, contemporaneamente, uma

\footnotetext{
${ }^{2}$ Em meu livro $A$ solidão tropical: a modernidade do Brasil e de Alencar, estudo a construção da modernidade no Brasil e na Europa e proponho uma releitura da narrativa e do papel de Alencar como
} 
discussão presente em Rousseau. Em seu Devaneios do caminhante solitário, procede ao funeral de uma esperança esfuziante que, antes, ele mesmo louvara na escrita do Émile e do Contrato social. Essa vontade de construção feita "custe o que custar" e "apesar dos pesares", que um dia caracterizou o pacto com o moderno, não escondia sua rota de Fausto, na dúvida que esboça e no desencanto que traz em seu bojo, instâncias que o romantismo palmilharia, ao intuir e discutir a perda das ilusões dos homens no mundo das mercadorias. Por sua formação em conformidade com a ambigüidade do moderno, os textos romanescos tratados nesta análise pressupõem reação amparada pelo movimento crítico de uma consciência voltada a questionar o desencantamento do mundo, provocado pelas promessas não cumpridas de desenvolvimento e igualdade social (brotadas e abortadas) à luz da técnica e dos empreendimentos do capital. Ambíguo no nascedouro, o projeto moderno se realiza como uma aventura do paradoxo, ao carregar, simultaneamente, impulsos de modernidade e de contramodernidade. Ou seja, ao transportar, como se fora o ovo da serpente, o veneno e o contraveneno de uma voraz vontade de poder.

$\mathrm{E}$ isso porque, de um lado, a modernidade descortinava oportunidades sem paralelo, construindo uma mitologia de futuro e progresso. Mais ainda, construindo a promessa da felicidade individual e do bem-estar social por meio do progresso. Por outro lado, essas oportunidades se revelaram cada vez mais restritivas, já que ao alcance de poucos, o que tornaria a redenção burguesa dos beneficiários do progresso muito pouco representativa, mesmo se apenas pensássemos na magnitude numérica de vidas no planeta. Isso acarreta que a ambigüidade do mundo moderno culmine por acentuar-se, de forma exacerbada, na desigualdade e no mal-estar da sociedade contemporânea, que, ao produzir e exibir grandezas, distribui miséria em profusão, retendo a riqueza em poucas mãos.

Nas obras aqui abordadas, a ficção se produz como imaginação que supera o horizonte determinista do historicismo, do nacionalismo e da etnia em senti- 
do estrito, ainda que a matriz desses traços nelas esteja latentemente aludida e não embaçada ou ausente. Tais obras configuram, portanto, um tipo de ficção que discute e reformula, de modo específico em cada um dos romances, o projeto de razão em marcha na modernidade ocidental desde o Iluminismo (KOSELLECK, 1999). Essa imaginação ficcional é fundamento de uma reflexão crítica da maior validade, pois nela a forma estética porta em si também uma interferência e um compromisso ético, que não deixa de lado nem a qualidade da escrita, nutrida pela força da auto-referencialidade da linguagem artística, nem a reflexão crítica e profunda sobre os desconcertos do mundo em face da condição humana e social, a que a arte também remete.

Conceber a ficção como imaginação histórica significa dizer que ela se faz mediadora entre o estético e o político, já que compartilha um elemento comum a ambos: o fato de que, ao encontrar as ruínas do pensamento, torna-se, ela própria, ruminação, revelando-se reflexão e crítica. Ou seja, realizando-se como um novo pensamento que brota de dentro das ruínas do pensamento. São ficções da crise (HELENA, 2005: 89-108).

A lei, o aparelho burocrático e judicial são motivos que atravessam essas obras, de forma algumas vezes direta. Em contenda com eles, seus personagens são seres à deriva, mergulhados à revelia na conturbada trajetória das crises, à mercê de um processo de desumanização. O teor naturalista de algumas passagens é uma forma de rasura do próprio naturalismo, que resulta adensado e que, pela corrosão a que procede, estimula no leitor a sensação de estar mareado em terra firme. O padrão naturalista requisitado enfatiza o abismo da razão e o fio da navalha em que se inserem aqueles personagens, localizados em situações limítrofes. Seus personagens correm risco, protagonizando uma versão "faca só lâmina" da existência. Nada inteiriços fragmentam-se, tornando-se como que traços espacejados de uma vontade de sobrevivência. E, na medida em que prosseguem sua luta, estilhaçam a ideologia que fabricara a crença na finalidade de um mundo burguês e "feliz" e na validade do uso de "qualquer meio", se necessário, para atingir tais fins.

Essas ficções podem ser relidas a partir de um pressuposto extremamente oportuno, reativado por Lucien Goldmann em Le Dieu caché, obra em que o autor oferece bases teóricas para utilização da expressão visão de mundo como um conceito crítico de alta valia. Diz Goldmann que toda grande obra literária ou artística é a expressão de uma visão de mundo, e que esta é um 
fenômeno da consciência coletiva que atinge o máximo de clareza conceitual na consciência do escritor. Acrescenta ainda que a visão de mundo é a expressão psíquica de uma relação entre certos grupos humanos e o meio social e natural (GOLDMANN, 1959: 28-29). Tão múltiplas e tão variadas são as situações históricas concretas que as visões de mundo tornam-se a expressão de um grupo de seres relativamente constantes nessa multiplicidade de situações reais.

A possibilidade de uma filosofia e de uma arte que guardam o seu valor para além do lugar e da época em que nascem, repousa principalmente no fato de que exprimem sempre a situação histórica transposta sobre o plano dos grandes problemas fundamentais que colocam as relações do homem com os outros homens e com o universo. (GOLDMANN, 1959: 30)

Ao contrário dos modernistas, que pretendiam uma ruptura com o passado, a narrativa de Lispector e de Coetzee, antes referidos, busca pensar a tensão dos modelos da modernidade em confronto com o cenário de uma modernidade tardia. E remete o leitor aos valores da arte como forma de refletir, através dos significantes que mobiliza, acerca do modo de produção do capitalismo tardio, na extrema fluidez do volátil cenário pós-moderno.

Nossa época recupera algo que pode ser visto como o rompimento das conexões perfeitas entre a parte e o todo. Somos de um tempo que suspeita não haver uma via de acesso garantido a uma totalidade infinita. Mas, paradoxalmente, temos também a nostalgia dessa perda. Em um sentido nada conservador, Vida e época de Michael K tematiza uma tal limitação e discute, a contrapelo, a onipotência e a arrogância desse desejo. No espaço precário da identidade não plena, Michael não pode ver tudo, nem o todo. Colhido entre a vontade e o involuntário, resta-lhe espiar e espreitar o detalhe, que, todavia, contém a pluralidade de resíduos a que se filia seu olhar observador, numa trama surpreendente.

As formas predominantes da configuração da modernidade como um projeto não uniforme que, ricamente, se esgarçava ao nascer, revelaram uma maneira de, na passagem do século XX ao XXI, configurar o elogio da diferença entre o eu e o outro e do eu consigo mesmo, num reencantamento da subjetividade como descoberta do homem e da capacidade de criar (e de se 
perder) enquanto autenticidade e destino. A insistência de grandes teóricos do pós-modernismo de resumirem essa diferença ao elogio das minorias e à fragmentação esquizóide de um sujeito cindido, tornado simulacro de simulacros, talvez não seja o antídoto, como se pensa, para a arrogância da razão instrumental que, na distante fronteira finissecular do século XVIII, havia se definido e daí proliferou.

Na migração e interconexão constantes entre observar, andar e viajar, vale lembrar que tanto em $O$ processo, Vidas secas, $A$ hora da estrela como em Vida e época de Michael $K$ as imagens são onipresentes. Michael $K$ detecta, numa delas, a das sementes de abóbora, um fio de esperança. Sem indiferença ao mundo e sem imaginar que ele seja, como alguns hoje apregoam, fruto do discurso, Vida e época de Michael K sublinha a exaustão do mero elogio da diferença. Processa, antes, uma construção em abismo: a reminiscência do desejo da viagem da mãe dentro da viagem do filho, em que todas as imagens se imiscuem. É na química dessa imagem que emerge a semente que pode fundar (ou não) um novo horizonte, em que o sujeito e a subjetividade ainda são possibilidades de sentido. E de uma utopia do precário, é verdade, realmente humana. Em outro lugar tratamos da peculiar relação de Michael $\mathrm{K}$ com a terra, em que ele se enterra (HELENA, 2006b).

No cenário e no imaginário dessas ficções, duas das principais vertentes da modernidade e do moderno estão embutidas e discutidas. Em sua ambigüidade, a modernidade nascera luz e sombra. Apostava suas fichas na razão e na tecnologia, ainda que, por outro lado, se visse aquinhoada com as potências da intuição, do delírio e da loucura. Era como se, ao homenagear o progresso, dele também suspeitasse.

O processo, Vidas secas, A hora da estrela e Vida e época de Michael K configuram um tipo de imaginação histórica que discute e reformula, de modo específico em cada um dos romances, o projeto de razão em marcha no contexto ocidental desde o Iluminismo até os tempos atuais, de modernidade tardia. Essa imaginação ficcional é fundamento de uma reflexão crítica da maior validade, por meditar sobre a diferença entre o que foi prometido e o que de fato aconteceu, no trabalho magistral de uma literatura que opera no campo minado da fronteira entre a referência e a auto-referência. Sem que produzam uma obra engajada no sentido da teoria do reflexo, quase aliada do panfleto, os romancistas aqui abordados conseguem percorrer o difícil equilíbrio 
(sempre tenso) entre a representação e o irrepresentável, o que certamente implica a responsabilidade do escritor diante de seu texto e de seus leitores (cf. SELIGMANN-SILVA, 2003: 376-9).

Os choques da vivência moderna, afirmou Benjamin em seu estudo sobre alguns temas em Baudelaire (1936), modificaram o nosso modo de ver e de representar o mundo. Que dizer, então, da experiência de vida hoje em dia, quando uma violência vertiginosa se imprime sobre os habitantes do globo, acionando o terrorismo, o fundamentalismo e a indiferença pelo que é ético ou antiético, na vida, nas artes? E quando na mídia e até na literatura o aparato estético pode tomar o lugar da ética, da capacidade de pensar, e desalojar valores fundamentais para a vida social?

Um exemplo flagrante de que a literatura e as demais artes se realizam na confluência tensa da captação do real e sua simultânea desrealização ficcional encontra-se num documentário sobre o fato de que, durante a II Guerra Mundial, em 1944, um dos judeus levados para o campo de Theresienstadt foi encarregado de filmar seus companheiros a fim de que os nazistas apresentassem o material daí resultante aos observadores da Cruz Vermelha, tornando público o "bom trato" dispensado aos judeus por seus carcereiros nazistas, nas câmaras de tortura a que chamavam de campos de trabalho. Conhecedor profundo da técnica e dos efeitos estéticos que podia obter pela manipulação de seu instrumental de trabalho, o documentário que realiza sob ameaça apresentou o campo nazista como um jardim de harmonia. Enganou-se, inicialmente, com isso, o enviado da Cruz Vermelha, que saiu de lá com a impressão de que os judeus eram tratados com alguma dignidade. No entanto, ao término dos trabalhos, e abatido pela tarefa que o aviltava e à qual só teria podido renunciar pela própria morte, o cineasta judeu confessou que, se o obrigaram a fabricar um "registro" palatável construído por ele graças aos recursos estéticos de recorte, com os quais mascarou a terrível realidade do que era vivido naquele campo de concentração, por outro lado, apesar de toda a técnica, não lhe foi possível retirar a dor dos olhos de seus atores.

Tocando em questão muito próxima, Klaus Mann escreveu Mefisto, romance de que resultou um bom filme de mesmo nome. A história se passa na Alemanha nazista e conta o dilema de um ator que, ao ver os colegas abandonarem o país, decide ficar, pois considera que, em seu trabalho, a língua alemã é indispensável. Em um arriscado nivelamento entre "minha pátria, 
minha arte e minha língua", ele termina servindo aos nazistas, traindo aqueles que amava. Ocultando de si mesmo a vontade de poder que o fez ficar e preparar um Fausto nazista, dedicando-se a um cuidado estético apurado, ele não é capaz de perceber que, em tempos de catástrofe, tanto o silêncio, geralmente povoado de possibilidades de crítica e defesa, quanto a língua podem ser apropriados e utilizados de modo conivente.

Considerando o conjunto de fatores que gerou o nazismo e o Holocausto, nos anos 1930-1940, e a penúria de valores de que se avizinhou o mundo contemporâneo, a ponto de se observar por todo lado uma falta da capacidade de julgamento e de responsabilidade do leitor e do cidadão, é oportuno relembrar que os romances de que estamos tratando, de várias e indiretas maneiras, consideram o autoritarismo e a crise da consciência social como produtores de uma ambiência lesiva para os homens. O processo (1925), Vidas secas (1934), A hora da estrela (1977) e Vida e época de Michael K (1983) são textos que apresentam e discutem tal panorama, tanto no momento crítico da modernização de inícios do século passado, quanto na atualidade. Atravessam o caminho de Fabiano e de Macabéa forças corrosivas e incontornáveis que também rondam o confinamento do personagem Josef $\mathrm{K}$., de O processo. Como o Senhor K, que é julgado por um tribunal que não se faz visível, e que o deixa sem defesa nem escapatória, Fabiano, Macabéa e Michael K são seres sem condição de luta, condenados à violência do mundo. Encontram-se à margem da burocracia do aparato estatal, que lhes escapa à compreensão e força-os a sempre se deslocarem, na fuga inglória dos que não têm direito a pouso nem a repouso.

\section{Terra inóspita, mar sem abrigo: Michael K, Lucy Lurie e Elizabeth Costello}

Na paisagem da modernidade tardia (ou do capitalismo líquido ${ }^{3}$, no dizer de Zygmunt Bauman) esvaziam-se, mundialmente, os estados nacionais. Nesse

\footnotetext{
${ }^{3} \mathrm{O}$ termo é cunhado por Zygmunt Bauman. O autor define a modernidade líquida como "a presente fase, nova de muitas maneiras, da história da modernidade" (BAUMAN, 2001: 9). Segundo ele, "a
} 
sentido, resta ainda examinar, no campo da opressão e da exclusão, que a narrativa de Kafka como que inaugura magistralmente, no modernismo, um aspecto da construção de Michael K, por J. M. Coetzee, que dele se utiliza para cogitar acerca da realidade cultural e política da África do Sul e, em tese, para pensar a situação de exclusão que contemporaneamente atinge dimensão planetária, indo muito além de topologias específicas. Em Vida e época de Michael $K$, a apresentação do protagonista Michael ao leitor inicia de chofre o romance, sublinhando a condição precária e grotesca do personagem:

A primeira coisa que a parteira notou ao ajudar Michael $\mathrm{K}$ a sair de dentro da mãe para dentro do mundo foi que ele tinha lábio leporino. [...] Para a mãe, disse assim: "Devia ficar contente, eles dão sorte para a casa". Mas desde o começo Anna K não gostou da boca que não fechava e da carne viva e rosada exposta para ela. [...] Como ficava magoada com os sorrisos e cochichos, manteve o menino afastado de outras crianças. Ano após ano, Michael K ficou sentado em cima de um cobertor vendo a mãe limpar o chão dos outros, aprendendo a ficar quieto. (COETZEE, 2003: 9-10)

Ao longo desse e de outros fragmentos, vai-se delineando a indigência, a ignorância e a aparente tolice de Michael K, com seu grotesco lábio leporino. A não-identificação do leitor é evidente. Todavia, vai sendo pouco a pouco agarrado pelo visgo de um personagem invulgar. Em torno de Michael se estabelece um pacto perverso, e a rede social, na qual a banalização do mal se torna patente, o envolve no malévolo, dimensão que não o caracterizará, embora o personagem nela se encontre mergulhado - ou seja, mesmo que instalado no sistema do mal, Michael dele não faz parte intrinsecamente.

Por um lado, um pária desde o nascimento, Michael é um "estranho" no ninho, pois ele se distingue pela força de integridade que representa, mesmo

modernidade pesada foi a era da conquista territorial. A riqueza e o poder estavam firmemente enraizadas ou depositadas dentro da terra - volumosos, fortes e inamovíveis como os leitos de minério de ferro e de carvão" (BAUMAN, 2001: 132; grifo meu). Diferente da modernidade sólida (ou pesada ou, ainda, o chamado fordismo), na modernidade líquida, o "trabalho sem corpo da era do software não mais amarra o capital: permite ao capital ser extraterritorial, volátil e inconstante” (BAUMAN, 2001: 141). 
na fragilidade de seu desamparo. O personagem é constituído sob o vaticínio da melancolia, que freqüentou, no modernismo de um Augusto dos Anjos ou no de um Carlos Drummond de Andrade, a melhor poesia brasileira de extração existencial. E dele quase se pode dizer, parodiando Drummond: "Vai, Michael, ser gauche na vida".

Por outro lado, nada nele deixa entrever que essa condição o fere, desespera ou impede sua construção íntima de ser dotado de dignidade e padrão ético e afetivo. Singularíssimo, se de um lado é um pária, pois para ele não há um lugar reservado no horizonte burguês, por outro, ocupa a situação de sujeito dotado de compromisso ético, o que traduz na relação com a mãe, com o mundo e consigo mesmo. Num ambiente sul-africano adverso, e com características que os brasileiros, apesar da distância, vivenciam no cotidiano, como as balas perdidas (COETZEE, 2003: 18-19), o desemprego (COETZEE, 2003: 12), a falência da rede hospitalar (COETZEE, 2003: 11), a burocracia impeditiva (COETZEE, 2003: 27) e outras, menos familiares a nós, como a necessidade de passe para deixar a Cidade do Cabo (COETZEE, 2003: 16-17), Michael transforma o projeto de sua mãe, Anna $\mathrm{K}$ - "sair de uma cidade que lhe prometia tão pouco e voltar para a tranqüilidade do campo, de sua meninice" (COETZEE, 2003: 14) -, em um sonho cuja realização ele chama para si:

Agora era a hora. Assim que voltaram para o quarto, botou para fora o plano que estava elaborando desde que construíra o primeiro carro. Estavam perdendo tempo, esperando os passes. Os passes não iam chegar nunca. E sem os passes não poderiam ir de trem. Qualquer dia desses, iriam ser expulsos do quarto. (COETZEE, 2003: 26)

A decisão de partir (escapar, fugir dali) é tomada. Põe-se em marcha o percurso da migração, que faz com que Michael e Anna tomem "a rota mais curta passando pela área devastada, em torno dos velhos tanques de armazenamento de combustível, onde a demolição dos edifícios queimados tinha acabado de começar" (COETZEE, 2003: 28). Essa migração resulta na perplexidade do narrador, pois a deambulação de Michael, iniciada como fuga, se caracteriza como algo muito maior, manifestando-se como uma forma alternativa de viver a condição inóspita que lhe fora reservada. Descortina- 
se uma identidade mutante, para Michael e para a África que ele representa. Uma formação identitária complexamente apreendida, que sugere e estimula a pergunta: - Quem é você, Michael, esse outro inapreensível, para o qual a sociedade africana não tem lugar, apesar de você estar por toda parte e em todos os lugares?

No espaço aberto por essas dolorosas e imperiosas questões que, de resto, permanecem sempre em pauta e não admitem resposta única, o texto parece refluir, por sua dimensão alegórica, a uma zona nublada de mitologia, construindo para o personagem a sugestão de uma identidade não estática, mas porosa e rarefeita, na qual tempos e espaços incongruentes se amalgamam de forma inusitada:

Você é precioso, Michaels, do seu jeito; é o último da sua classe, uma criatura que sobrou de uma era anterior, como o celacanto, ou o último homem que falava a língua Yaqui. Nós todos tropeçamos e caímos dentro do caldeirão da história: só você, ao seguir sua luz idiota [...], ao escapar da paz e da guerra, ao se esconder no aberto onde ninguém sonharia olhar, conseguiu sobreviver do jeito antigo, flutuando pelo tempo [...]. (COETZEE, 2003: 176).

Essa identidade rarefeita é apresentada numa tríade, a partir da qual o personagem é nomeado como Michael K (COETZEE, 2003: 9-25), Michael (COETZEE, 2003: 27-147) e Michaels (COETZEE, 2003: 151-193). O primeiro batismo, Michael K, revela seu parentesco com as alegorias de Kafka, e remonta a Josef $K$, enovelado num processo que o penaliza sem que ele jamais saiba por quê. O segundo, Michael, remete ao homem sem cidadania, ao pária em migração por caminhos que não levam a lugar nenhum, numa fuga sem paradeiro, em que o lastro de liberdade se vai tornando uma possibilidade apenas íntima, pois está vedada a sua integração social. O terceiro, o Michaels, no plural, aponta para uma alegoria da coletividade de párias, para a leva sempre maior dos sem-terra e dos sem-teto que, no entanto, resistem, até a morte, para além dos limites da vida hedionda que lhes é imposta.

A questão identitária não se realiza mais, como se vê, pela via de Rousseau: Michael K não é apresentado como um personagem cujo eu será matéria de aprofundamento. Esse estatuto burguês, do qual ele não participa, e que ele não reivindica, faz com que Michael não seja nem profundo, nem superficial. 
Ele é corpo e gestos, sua fala, um grunhido quase incompreensível, mas tudo nele revela uma consistência que o identifica e distingue dos demais. Como não há um mergulho investigativo do próprio eu, o adensamento é feito pela mudança de foco narrativo e pela constante deambulação do personagem por um espaço que é, ao mesmo tempo, coisa material e coisa mental. É o narrador, ou melhor, são os vários focos narrativos que se encarregam de, por meio do olhar, aproximar o leitor dessa investigação, oferecendo hipóteses - especialmente a alegórica - para "desvendar", rasurar e articular, na cadência da metamorfose, o personagem e seu destino inapelável no qual se inscreve uma condição de anomia, que transforma os seres em "vítimas sacrificiais" de uma "peste" que a tudo contamina em uma sociedade ameaçada perigosamente pela violência disseminada e pela voracidade de um poder que não tem alternância e se repete em longa e insuportável duração.

Michael é uma alegoria da história e da África no sentido benjaminiano do termo. O personagem compõe-se como cacos de um eu estilhaçado, ao qual o leitor tem acesso não exatamente pelo que o personagem diz de si mesmo, mas pelo olhar multiplicador dos seus focalizadores. Michael é, de certo modo, fruto de plantação e de colheita da refinada escrita de Coetzee e de sua sensibilidade ética. O campo para onde ele quer ir (e vai, ao longo de sua fuga-libertação) é da natureza metafórica dos campos não apenas visíveis, do mesmo modo que ele não é um rescaldo melancólico do mito do paraíso perdido nem mera recuperação das utopias romântico-nostálgicas:

Sua estada no campo foi apenas uma alegoria. Se você conhece essa palavra. Foi uma alegoria, falando no nível mais elevado, de como um significado pode, escandalosamente, exorbitantemente, se instalar dentro de um sistema, sem passar a fazer parte dele. (COETZEE, 2003: 192)

Uma burocracia impiedosa, de inominável violência, penetra em todos os meandros e faz com que a própria hospitalização do personagem consista em uma instância de sofrimento a mais; Michael é, no entanto, em seu corpo debilitado, uma forma estranha ao mundo que o cerca, o que confere a ele mesmo uma espécie de configuração de lugar de liberdade. A liberdade de quem diz: não posso e, assim sendo, não compactua com o que considera nefasto. O riquíssimo personagem de Coetzee é um lugar de reflexão, de 
rememoração e de prospecção do próprio ato de narrar, na confluência entre a vida e uma escrita que o implanta como corpo, texto envolvente, semente.

Deixe eu falar do sentido da sua sagrada e sedutora plantação, que floresce no coração do deserto e produz a comida da vida. A plantação para a qual você está indo agora está em nenhum lugar e em todo lugar, menos nos campos. Ela é o outro nome para o único lugar onde você se integra, Michael, onde você não se sente sem teto. Está fora de todos os mapas, nenhuma estrada que seja só uma estrada leva até ela, e só você sabe o caminho. (COETZEE, 2003: 192-3)

Essa ficção de Coetzee é, como já dissemos, herdeira das narrativas que se prendem a duas tradições: a da captação do eu profundo pelo próprio eu (na linha aberta por Rousseau) e a da rasura dessa investigação, que resta impedida pelo desencantamento (cf. LÖWY: 1995) do mundo (no sentido de alienação), no qual as relações intensificaram o processo de reificação social, gerando cisões cada vez mais radicais no sujeito e na subjetividade. Apesar disso, a narrativa não retoma a forma passada, antes a reinventa. Ainda que privilegie, como um Kafka, o ceticismo e a tragicidade, nela a comunicação entre o narrador e seu personagem não fica barrada, pois Coetzee opta por uma restauração da afetividade, o que se dá na aliança de que se reveste o olhar amoroso que, ao longo dos diversos patamares narrativos, o narrador lança a seu personagem construído na fímbria da miséria e do sublime. Se o romance é, como queria Lukács, a narrativa do homem solitário e do herói degradado numa sociedade degradada, a linguagem narrativa adotada na ficção de Coetzee, ao tomar a questão africana como ponto fulcral, valida a diretriz da responsabilidade ética, vista como recurso inadiável para o momento que atravessamos.

Acerca da pergunta inicialmente lançada (ainda que entre parênteses) - de como e com que linguagem construir o idioma e as práticas da independência -, a reflexão literária de Coetzee oferece gama variada de encaminhamentos.

O primeiro deles, em Vida e época de Michael K, toma um personagem triangular - Michael K, Michael, Michaels - e nele faz representar a tragédia dos direitos coletivos numa sociedade carente de cidadania plural, termos que jogam com as tensões entre diferença e igualdade, entre a afirmação comum da dignidade humana e a exigência de reconhecimento da responsabilidade. 
O segundo faz de Elizabeth Costello ${ }^{4}$ (para alguns críticos essa personagem de ficção seria um alter ego do escritor) um dos mais importantes textos de Coetzee em que a África é posta diretamente em pauta. Por meio do contraponto de dois personagens, a escritora australiana Elizabeth Costello e o ficcionista nigeriano Emmanuel Egudu, e de suas contendas verbais sobre o que vem a ser a literatura africana (e o propalado, por Egudu, "romance oral”, considerado um absurdo conceitual por Elizabeth Costello), a narrativa alerta para a necessidade de se elaborar uma linguagem da emancipação. Mas de uma emancipação não mais comprometida em panfletar o real, nem em expor a mística do africano como último repositório das energias primais humanas, mergulhadas no exotismo e em suas seduções.

Elizabeth Costello, que se relacionou eroticamente com Emmanuel Egudu no passado, hoje não gosta de Egudu, justamente pelo caráter manipulador através do qual ele mistura conceitos deturpados de oralidade a fim de, com isto, granjear a simpatia dos burgueses ricos, medianos e incultos que viajam no navio de cruzeiros no qual ele e Elizabeth são entertainers exibidos como intelectuais de animação. As palestras de Egudu sobre a oralidade são uma espécie de literatura africana para turista, nas quais ele deturpa, de forma populista, trechos de Paul Zumthor, e não se vexa de formular teorias sobre o romance "oral", o que deixa Elizabeth Costello absolutamente irritada:

\footnotetext{
${ }^{4} \mathrm{O}$ livro, composto de palestras, traz em si uma migração de textos muito peculiar. Dois dos contos (palestras) já apareceram em outro livro de Coetzee, $A$ vida dos animais, em que Elizabeth vai ficar na casa do filho por poucos dias, já que foi convidada a apresentar-se como conferencista no Appelton College, onde seu filho é professor de Física. Além de não se dar com a nora, Norma, que a considera uma radical vegetariana, Costello provoca verdadeira comoção com suas duas palestras, ao mexer em questões delicadas e controversas, como a do nazismo e a comparação entre os judeus e os animais que vão para os abatedouros, o que lhe causa protesto de um professor judeu, que se recusa a jantar com ela. A composição do livro reúne textos de personalidades da vida acadêmica mundialmente reconhecidos, e a mescla entre o ensaístico, o não-ficcional e o ficcional transforma o livro num amálgama em que a ficção se dá no limite com o que lhe vai além e lhe fica aquém. Ao reunir esses dois textos a outros seis na obra Elizabeth Costello, Coetzee produz um efeito de "ampliação" na biografia de sua personagem, dando-lhe uma irmã religiosa, o que provoca uma revisão de problemas não só científicos e artísticos, mas também metafísicos. O livro e seu duplo, $A$ vida dos animais, compõe um dialogismo que permite também articulá-los a um outro "par", Juventude e Infância (também intitulados Cenas da vida provincial I e II), no qual a questão da biografia e da alterbiografia surge como um desafio retomado em Costello e em A vida dos animais.
} 
O que a irrita em Emmanuel, o que ela tem o bom-senso de não falar [...] é o jeito como ele transforma toda discordância numa questão pessoal. Quanto ao seu [dele] querido romance oral, sobre o qual construiu a carreira de palestrante, ela acha a idéia em si mesma confusa. Um romance sobre gente que vive numa cultura oral, gostaria de dizer, não é um romance oral. (COETZEE, 2004: 61).

Uma terceira alternativa de encaminhamento da questão - com que linguagem criar uma ficção africana? - é formulada por Coetzee em Desonra, o romance que, como já foi dito, conquistou o segundo Booker Prize para o autor. O texto apresenta nova forma de observar e de representar a relação entre negros e brancos nas fazendas da África, e acompanha a queda em desgraça de David Lurie, um professor de poesia da Universidade Técnica do Cabo que não consegue se situar nem no mundo acadêmico nem na conturbada realidade da África do Sul, mesmo após o apartheid. Em prosa límpida, em que nada se desperdiça, à maneira de um Graciliano Ramos, o romance mergulha na disputa pela terra, numa sociedade dilacerada pela crise, pela pobreza, pela criminalidade. E na qual se dá o embate para um ajuste de contas entre o passado colonial e o presente estilhaçado de uma África que não é mais o que foi, mas que também ainda não dispõe da linguagem que a constitua livre.

\section{Pensar, criticar e emancipar, formas de uma reinvenção coletiva}

Nos três textos - Vida e época de Michael K, Desonra e Elizabeth Costello -, e guardadas as especificidades dessas obras, alguns impasses se repetem e as identificam. Todos eles recusam as explicações fáceis, as análises ligeiras, e sublinham que é preciso elaborar uma provocação (e resposta, por que não?) artística que tome a cargo discutir formas de representação além de um sociologismo primário. A ficção de Coetzee alerta para isso, apontando como é difícil e longo o processo de reinvenção coletiva da emancipação. Um processo no qual está em causa não apenas a antiga África colonial, mas o que dela ainda permanece na África dita pós-colonial. Um processo no qual a literatura que lá se produz é, ainda, escrita na lingua do colonizador. E, nessa forma de 
veicular o momento tenso da separação, quem sabe não só o pós-colonizado se expresse, mas talvez o explorador também ainda nela se explane.

Deste modo, e não por acaso, uma tríade alegórica ganha forma nas três narrativas de Coetzee aqui privilegiadas. Ela se realiza em torno dos temas da boca, da oralidade e da língua, formando-se um constelado de associações riquíssimo, que reúne as três obras numa espécie de reflexão em processo. Por meio desse constelado, indicam-se, de modo criativo, três matrizes da sustentação cultural e material que envolve o mundo dos personagens e o caracteriza em suas necessidades básicas: o alimento, a luta pela sobrevivência e a comunicação, que insistem, reunidos e reunindo o mundo fragmentado dos personagens precários, no âmbito de uma literatura que demarca e questiona esse horizonte do precário como reserva do humano e do desumano.

No primeiro livro, Vida e época de Michael K, o lábio leporino do personagem impõe-lhe destino grotesco. No segundo livro, Elizabeth Costello, sublinham-se os prejuízos de um equivocado culto da oralidade, por parte de Egudu, o escritor nigeriano desfrutável, além de examinar-se a "má consciência do intelectual" num mundo marcado pela violência. No terceiro, Desonra, a questão que avulta é a do idioma. Ou seja, constatados os problemas, expostos os eixos em que tudo se move, no rastro da violência que reúne, no pós-apartheid, descendentes dos colonizados e descendentes de colonizadores, resta discutir (e construir?) a instância de linguagem que há de ser legitimada como língua da reinvenção coletiva, como línguagem da emancipação. Destaca-se, a esse respeito, uma inquietação do personagem David Lurie ${ }^{5}$, que se mostra cada vez mais desconfiado e inquieto com a (im)propriedade de se tomar o inglês como a língua a transportar a ficção sul-africana.

\footnotetext{
${ }^{5}$ Enquanto examina a estranha reação do negro Petrus depois do estupro de Lucy, David Lurie, seu pai, por meio do discurso indireto do narrador, tece considerações sobre a África pós-apartheid, referindo-se, agora, à questão da língua através da qual, na vida e na literatura (não esqueçamos que David Lurie é um professor da área de humanas), a África deve se expressar: "Ele ia gostar de ouvir a história de Petrus um dia desses. Mas de preferência não reduzida ao inglês. Cada vez mais está convencido de que o inglês não é a língua adequada para a verdade da África do Sul. Em inglês, a história se transformou num código e longos trechos dela engrossaram, perderam sua articulação, articulosidade, sua artificiosidade. Como um dinossauro a expirar e a se assentar na lama, a linguagem endureceu. Apertada no molde do inglês, a história de Petrus pareceria artrítica, ultrapassada” (COETZEE, 2000: 135-6).
} 
Em três magníficos romances, partindo da imagem do lábio leporino e chegando à menção da impropriedade da língua do colonizador para apresentar a verdade da África, Coetzee joga luz sobre as atuais relações entre a África e a permanência, em seu território, dos rastros da violência colonizadora. Se para o escritor "a minha pátria não é a minha língua", seus romances têm fornecido boa munição para que se questionem, com novas sugestões, outras estratégias, estranhas às línguas da dominação, para se pensar a África em sua literatura rumo à difícil trajetória da emancipação. Se a minha pátria não é a minha língua (ou é?), o inglês não seria nem a língua nem a pátria dos expatriados, exilados em seu babitat.

O exame, portanto, da "realidade literária" que emerge de um tal encontro evoca, como já apontamos, a relação pós-colonial entre a África e suas antigas metrópoles. Acredito que a reflexão de Coetzee pode em muito contribuir para iluminar um campo que tem crescido de modo alentado nos estudos de cultura no Brasil, e que no momento costumamos abrigar sob a nomenclatura de Literaturas africanas de expressão portuguesa.

Poderá esse título nos dizer de um abrigo? Ou arrisca-se a desviar ideologicamente, para o canto escuro da memória da colonização, a expressão africana da própria vida, em África, para a África e para os africanos? Uma nomenclatura, como sabemos, é sempre mais do que ela anuncia. Ou menos.

Mesmo não sendo David Lurie, também gostaria de ouvir histórias da África. Mas não reduzidas à expressão colonizadora, pois:

Em inglês, a história se transformou num código e longos trechos dela engrossaram, perderam sua articulação, articulosidade, sua artificiosidade. Como um dinossauro a expirar e a se assentar na lama, a linguagem endureceu. Apertada no molde do inglês, a história de Petrus pareceria artrítica, ultrapassada. (COETZEE, 2000: 136).

Além disso, ao falarmos de uma literatura africana de expressão portuguesa não nos devemos esquecer, nem embaçar esse fato, de que "a conquista ibérica desse primeiro capítulo da história da colonização européia 'transformou o mundo recém-conquistado em uma câmara de torturas"” (BENJAMIN apud LÖWY, 2005: 10). Enquanto isso, $\mathrm{K}$ se mexia inquieto, nas suas páginas: 
Sou mais como uma minhoca, pensou. Que também é uma espécie de jardineiro. Ou uma toupeira, também jardineira, que não conta histórias porque vive em silêncio. Mas uma toupeira ou uma minhoca num chão de cimento? (COETZEE, 2003: 209)

A vivência trágica dos ideais derrotados pela face de horror da modernidade, que teima em crestar a senda da esperança, é a matéria ígnea de que parte Coetzee. Com a batata quente desse elemento a queimar a mão, torna-se ao leitor possível retomar a dimensão inevitavelmente histórica da existência. Por isso, transitar pelo imaginário da Cidade do Cabo torna-se, via Coetzee, uma forma de deparar com uma dimensão local, mas, ao mesmo tempo, também universal. Falar da sua aldeia, como já foi assinalado por Adorno, foi e continua sendo uma forma de dirigir o olhar aos que, como Michael K, se encontram exilados do mínimo de dignidade por desígnios que não se decidem pelas mãos dos deuses e, sim, pela força das prioridades do homem.

Mas é preciso considerar que só dizer - a escrita, a palavra, o nome - algo fundamental não é, todavia, suficiente; pois, no homem, insistem: a boca, a fome e o abdômen. Ciente desse problema, outra riqueza do texto de Coetzee é saber evitar a rasura do populismo em que poderia deslanchar seu personagem "pobre". Coetzee não o transforma num descamisado.

Como na escrita de um Kafka, que demonstra conhecer bem, Coetzee faz da "inconclusão" uma forma de estar na escrita da crise. Sua compreensão da falta eleva a tematização do desamparo a um nível em que não se pode sentimentalizar vulgar e puramente. O tema da exclusão social é transformado em problema, tema formalmente encarnado. A consciência que se aviva no ato narrativo requisita a ruína, o duplo, o inconcluso, reassumindo os dilemas e fantasmas da modernidade ao construir a ambigüidade ${ }^{6}$ que transforma o que poderia ser mais uma narrativa da dor universal em um texto memorável, verdadeiramente fundamental.

\footnotetext{
${ }^{6}$ Uma referência ao processo de transformação do tema em forma, utilizando-se da expressão "ambigüidade da letra", encontra-se no posfácio de O desaparecido ou Amerika (KAFKA, 2003: 283).
} 


\section{Referências Bibliográficas}

BAUMAN, Zygmunt. Modernidade líquida. Tradução de Plínio Dentzien. Rio de Janeiro: Zahar, 2001. - Amor líquido. Sobre a fragilidade dos laços humanos. Tradução de Carlos Alberto Medeiros. Rio de Janeiro: Zahar, 2004.

. Vidas desperdiçadas. Tradução de Carlos Alberto Medeiros. Rio de Janeiro: Zahar, 2005.

COETZEE, John Maxwell. Vida e época de Michael K. Tradução de José Rubens Siqueira. São Paulo: Companhia das Letras, 2003.

- Desonra. Tradução de José Rubens Siqueira. São Paulo: Companhia das Letras, 2000.

. Elizabeth Costello. Oito palestras. Tradução de José Rubens Siqueira. São Paulo: Companhia das Letras, 2004.

- A vida dos animais. Tradução de José Rubens Siqueira. Intr. e org. Amy Gutmann. São Paulo: Companhia das Letras, 2002.

- Juventude. Cenas da vida na província II. Tradução de José Rubens Siqueira.

São Paulo: Companhia das Letras, 2005.

. O mestre de Petersburgo. Tradução de Luiz Roberto Mendes Gonçalves. 2. ed.

São Paulo: Companhia das Letras, 2003.

GOLDMANN, Lucien. Le dieu caché. Étude sur la vision tragique dans les Pensées de

Pascal et dans le théâtre de Racine. Paris: Gallimard, 1959.

HELENA, Lucia. A solidão tropical: a modernidade do Brasil e de Alencar. Porto Alegre: PUC/RS, 2006. (Grandes autores, 2)

. "Tempos de sombra: o nacional e o refugo da globalização". In: Anais do X Congresso Internacional da Abralic. Rio de Janeiro: UERJ, 2006.

. "O drama ilimitado e autodefinidor da ficção". In: Matraga, Revista do

Programa de Pós-Graduação em Letras/Universidade do Estado do Rio de Janeiro, ano 12. n. 17, p. 89-108, Rio de Janeiro: Caetés, 2005.

" "O coração grosso: migração das almas e dos sentidos". Alceu, Revista de Comunicação e Política, PUC/RJ, v. 1, n. 2, p. 63-76, 2001.

KAFKA, Franz. O processo. Tradução de Modesto Carone. Rio de Janeiro: O Globo; São Paulo: Folha de São Paulo, 2003. p. 211.

. O desaparecido on Amerika. Tradução, notas e posfácio de Susana Kampff

Lages. São Paulo: Editora 34, 2003. 
KOSELLECK, Reinhardt. Crítica e crise. Uma contribuição à patogênese do mundo burguês. Tradução do original alemão Luciana Villas-Boas Castelo-Branco. Rio de Janeiro: EdUERJ/Contraponto, 1999.

LISPECTOR, Clarice. A hora da estrela. Rio de Janeiro: Rocco, 1998.

LÖWY, Michael. Walter Benjamin: aviso de incêndio. Uma leitura das teses sobre o conceito de história. Tradução de Wanda Nogueira Caldeira Brant, Jeanne Marie Gagnebin e Maços Lutz Muller. São Paulo: Boitempo, 2005.

. Revolta e melancolia. O romantismo na contramão da modernidade. Petrópolis: Vozes, 1995.

RAMOS, Graciliano. Vidas secas. Rio de Janeiro/São Paulo: Record, 1998.

ROUSSEAU, Jean-Jacques. O contrato social: princípios do direito político. Tradução de Antonio Pádua Danesi. São Paulo: Martins Fontes, 2001. . Devaneios do caminhante solitário. Tradução de Fúlvia Maria Luiza Moretto. 3. ed. Brasília: UnB, 1995.

. Émile ou De L'Éducation. Paris: Garnier-Flammarion, 1966.

SELIGMANN-SILVA, Márcio. "O testemunho entre a ficção e o real". In: . (Org.) História, memória, literatura. O testemunho na era das catástrofes. Campinas: Unicamp, 2003. 